\title{
Population dynamics of the tropical bivalve Cardita affinis from Málaga Bay, Colombian Pacific related to La Niña 1999-2000
}

\author{
José M. Riascos · Olaf Heilmayer · Jürgen Laudien
}

Received: 12 June 2007 / Revised: 3 September 2007/ Accepted: 4 September 2007/Published online: 13 October 2007

(C) Springer-Verlag and AWI 2007

\begin{abstract}
The population dynamics of the "cholga" Cardita affinis (Sowerby 1833) from Málaga Bay, Colombia, was studied from December 1999 to February 2002, which included the 1999-2000 La Niña event (LN) and the post-LN period 2001-2002. This climatic deviation caused precipitation anomalies in Málaga Bay. Salinity, precipitation, and sea surface temperature anomalies were highly correlated with the bivalve's body mass cycle. Irregular spawning events were observed during $\mathrm{LN}$ by comparison
\end{abstract}

Communicated by S. Thatje.

Climate variability and El Niño Southern Oscillation: Implications for Natural Coastal Resources and Management. S. Thatje (ed.)

J. M. Riascos $(\bowtie)$

Instituto de Investigaciones Oceanológias,

Universidad de Antofagasta, Avenida Angamos 601,

Antofagasta, Chile

e-mail: josemar.rv@gmail.com

J. M. Riascos

INCIVA-Museo de Ciencias Naturales Federico C. Lehmann,

Zoology Research Group, Avenida Roosevelt 24-80,

Cali, Colombia

O. Heilmayer $\cdot$ J. Laudien

Department of Marine Animal Ecology,

Alfred Wegener Institute for Polar and Marine Research,

27568 Bremerhaven, Germany

e-mail: oheilmayer@noc.soton.ac.uk

J. Laudien

e-mail: Juergen.Laudien@awi.de

O. Heilmayer

National Oceanography Centre, Southampton,

School of Ocean and Earth Science,

University of Southampton,

European Way SO14 3ZH, Southampton, UK with the regular period. Individual growth and mortality were found significantly higher during $\mathrm{LN}$ than during the post-LN period while longevity was almost twofold lower during LN. Increased mortality was probably related to environmental stress. Individual production and productivity were higher during $\mathrm{LN}$, although the annual biomass was lower than during the post-LN period. These results may be related to higher food availability during $\mathrm{LN}$, which agrees well with the results on growth performance. The observed changes provide a base line for future studies regarding effects of El Niño/LN events on population dynamics of tropical bivalves.

Keywords Cardita affinnis - Estuaries .

Population dynamics $\cdot$ La Niña $\cdot$ Colombia

\section{Introduction}

Coastal marine ecosystems are largely governed by interactions of large-scale oceanographic conditions with climate and hydrology. This is particularly important in the high rainfall area of Pacific Colombia, where high river discharges characterize the environment (Restrepo and Kjerfve 2000; Kjerfve et al. 2001). The El Niño-Southern Oscillation (ENSO) however, causes a significant variability in regional rainfall, river discharge, and sediment load in this area (Restrepo and Kjerfve 2000). The warm episode El Niño (EN) causes drought conditions, while during the cold La Niña phase (LN) intense rainfall occurs in northern South America and in parts of Central America (Ropelewski and Halpert 1987). This is critical in estuarine environments, as ENSO significantly modifies local hydrology, in turn affecting ecosystem dynamics, and ultimately productivity (Peterson 2003). The hydrological 
anomalies associated with ENSO are therefore probably the most important forcing function for tropical marine ecosystems (Kjerfve et al. 2001; Urban 2001).

In South America, biological effects of ENSO have mainly been studied in economically important species from the highly productive Humboldt Current upwelling ecosystem (e.g. Wolff 1987; Arntz and Fahrbach 1996; Urban and Tarazona 1996). To various extents, marine resources are impacted negatively or positively by EN or $\mathrm{LN}$, depending on the intensity of the event, the onset and the adaptation ability of the species (e.g. Arntz 1986; Wolff 1987; Yamashiro et al 2002; Arntz et al. 2006). However, information on how the population dynamics of estuarine species are affected is still scarce (Riascos 2006).

The bivalve Cardita affinis (Sowerby 1833) is an abundant species in tropical estuarine rocky shores (Libbey and Johnson 1997; Garcia 2002) with a wide distribution range $\left(29^{\circ} \mathrm{N}\right.$ to $4^{\circ} \mathrm{S}$; Enquist et al. 1995). It is considered to be a suitable species for environmental studies, especially to assess effects of EN/LN for the following reasons: (1) this sessile bivalve lives attached in burrows drilled in a narrow zone of the lower estuarine intertidal rocky shore, therefore its population dynamics is likely to be affected by local hydrological and oceanographic changes (e.g. fresh water and nutrient input, sediment load, salinity, sea level, surface temperature), (2) C. affinis is a deposit feeding bivalve, its food availability is affected by hydrological and oceanographic changes, and (3) it is a broadcast spawner, therefore its settlement and recruitment largely depends on local circulation patterns. The aim of this study was to analyze and describe the population dynamics of the tropical bivalve $C$. affinis under changing environmental conditions, particularly the strong LN 1999-2000 event and the following post-LN period.

\section{Materials and methods}

Study area

The study was carried out in La Despensa $\left(3^{\circ} 55^{\prime} 57^{\prime \prime} \mathrm{N}\right.$, $77^{\circ} 20^{\prime} 55^{\prime \prime} \mathrm{W}$ ) in Málaga Bay (Fig. 1). This small bay of $126 \mathrm{~km}^{2}$ with a mean depth of $14 \mathrm{~m}$ is located in the Pacific central zone of Colombia. The zone is strongly influenced by the Inter-Tropical Convergence Zone (ITCZ): as the low pressure belt of the ITCZ moves north and south between $10^{\circ} \mathrm{N}$ and $3^{\circ} \mathrm{S}$, it passes over Málaga Bay and causes two rain periods, one from September to November and another one from April to June, interrupted by periods with lower precipitation. The study area is one of the regions with the highest annual precipitation in the western hemisphere $(7,000-11,000 \mathrm{~mm}$; Restrepo et al.
2002). The bay is characterized by a semidiurnal tide regime with an average range of $3.5 \mathrm{~m}$. Sea surface temperature (SST) remains nearly constant year-round, ranging between 26 and $29^{\circ} \mathrm{C}$ while salinity ranges between 18 and 27 (Rubio 1984).

\section{Sampling}

Quantitative monthly samples of $C$. affinis were taken from December 1999 to February 2002. Four stations (three replicates, using a $0.5 \times 0.5 \mathrm{~m}$ size quadrate) were sampled at $100 \mathrm{~m}$ intervals of an along-shore transect covering the entire zone, where $C$. affinis colonizes the rocky cliff (lower intertidal). Sampling was carried out during spring low tide. Maximum individual anterior-posterior shell length (SL) was measured to the lower $0.1 \mathrm{~mm}$ with a vernier calliper, thus obtaining monthly length-frequency distributions (LFD). From the quantitative samples, two sub-samples were selected (A: 30-35 individuals covering the available size range of $C$. affinis, 5-40 mm; B: 30-35 individuals $\mathrm{SL}>25 \mathrm{~mm}$ ). Sub-sample A was used to study body condition index (body mass cycle), while sub-sample $\mathrm{B}$ was used to study the reproductive cycle.

Salinity and SST were recorded in situ three times each sampling date by using a YSI sensor. Additionally, monthly SST data from Niño region $1+2\left(0-10^{\circ} \mathrm{S} ; 90\right.$ $80^{\circ} \mathrm{W}$ ) provided by the Climate Prediction Center-NOAA was included in the analysis to account for associations between large scale and local environmental variability. Monthly mean precipitation (MMP) was recorded by a meteorological station of the "Corporación Autónoma del Valle del Cauca" near the study area $\left(4^{\circ} \mathrm{N}, 77^{\circ} 02^{\prime} \mathrm{W}\right)$.

Body mass and reproductive cycle

To describe the body mass cycle, all soft parts were removed and dried to constant mass at $70^{\circ} \mathrm{C}$ in order to determine shell-free dry mass (SFDM). Ash-free dry mass (AFDM) was obtained by ignition at $550^{\circ} \mathrm{C}$ for $5 \mathrm{~h}$. A linear regression analysis was carried out to estimate the constants " $a$ " and " $b$ " of the allometric equation

$\log (\mathrm{AFDM})=\log (a)+b \times \log (\mathrm{SL})$.

This equation was used to estimate monthly variability of the shell size-mass relationship for a standard individual of $30 \mathrm{~mm}$ SL and to identify spawning events. Decreasing mass between two successive months was used as indication of a spawning event, while an increase over a longer period was interpreted as the developing phase before the spawning season (Urban and Tarazona 1996). Additionally, the monthly gonado-somatic index (GSI, 
Fig. 1 a Investigation area and monthly mean precipitation $\left(\mathrm{mm}\right.$ month $^{-1} ; 0.5^{\circ}$ resolution) averaged between 1961 and 1990 (Precipitation data from DWD/GPCC) b Location of the studied Cardita affinis belt at $\mathrm{La}$ Despensa
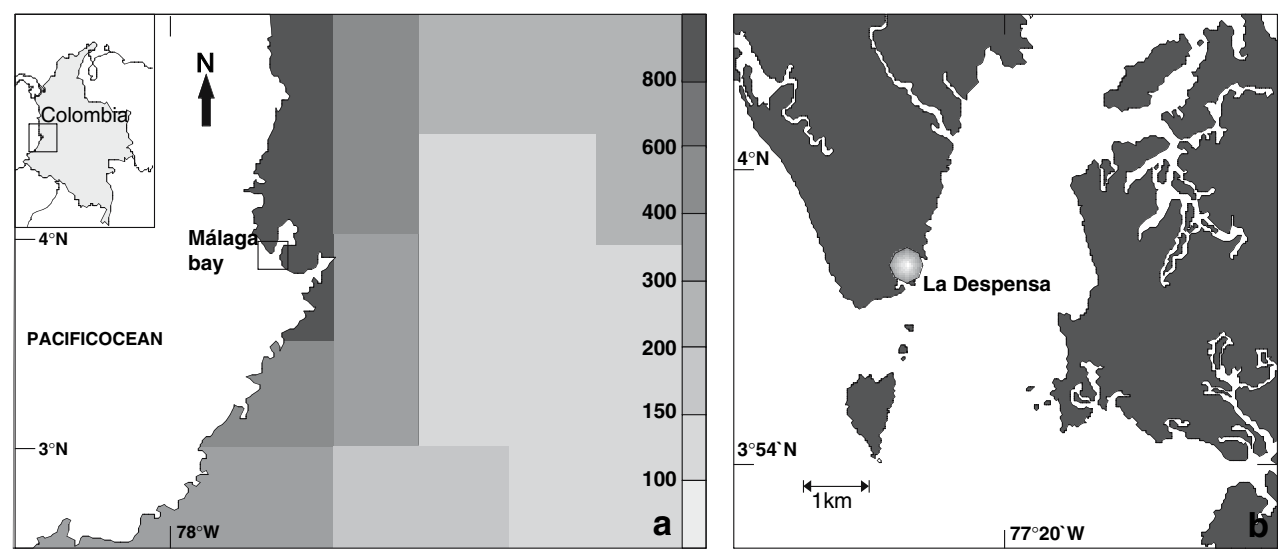

Eq. 2), defined as the relative volume of gonadal tissue $\left(V_{\text {gon }}\right)$ from the total body volume $\left(V_{\text {body }}\right)$, was estimated using a method based on linear measurements of the gonad region, which forms a sheath around the digestive gland (for details see Urban and Riascos 2002):

$\mathrm{GSI}=V_{\text {gon }} / V_{\text {body }} \times 100$.

Body mass may also be affected by short-term changes in food availability. To avoid this potential bias, we construed the body mass cycle in connection with gonad studies. For this we determined the gonad stage from microscopic observations on fresh gonadal material (smear samples). We used a semi quantitative scale proposed by Guillou et al. (1990), which allows to classify both males and females into four gonad stages: indifferent, ripe I, ripe II and spent. A Spearman correlation analysis was performed to evaluate the relationship between environmental parameters and variables describing the body mass and reproductive cycle.

\section{Growth}

Each month, 25-30 individuals were marked in situ with a carborundum disc of $1 \mathrm{~mm}$ thickness mounted in the mandrel of a portable electric grinder. In order not to disturb the bivalve too much, only a shallow groove was applied at the exposed anterior end of the shell, still leaving the bivalve attached in its burrow. The length from the groove to the anterior margin was measured with a vernier calliper to the nearest $0.1 \mathrm{~mm}$. A number tag for individual identification was fixed close to the borrow of each marked specimen. After different time intervals ranging from 1 to 6 months individuals were extracted from their cavities and SL at recapture time $\left(\mathrm{SL}_{\mathrm{t} 2}\right)$ recorded. $\mathrm{SL}$ at marking time $\left(\mathrm{SL}_{\mathrm{t} 1}\right)$ was estimated by subtracting the length increment (distance between the groove and the anterior shell margin) from $\mathrm{SL}_{\mathrm{t} 2}$. Two sets of tagging-recapture data were analysed independently. The first set consisted of 84 individuals recaptured during the period November 1999 to December 2000 (LN), and the second set of 97 individuals recovered from January 2001 until February 2002 (post-LN).

Growth was described by the von Bertalanffy growth function (VBGF; von Bertalanffy 1938):

$L_{t}=L_{\infty}\left(1-e^{-K\left(t-t_{0}\right)}\right)$

where $L_{t}$ is the length at age $t$ (year), $t_{0}$ the age at zero length, $L_{\infty}$ is the asymptotic length $(\mathrm{mm})$ and $K$, the growth constant $\left(\right.$ year $^{-1}$ ). Growth parameters $K$ and $L_{\infty}$ were estimated using Fabens' method (1965) by fitting a rearranged function of Eq. (3) to tagging-recapture data using the iterative non-linear least-square method (Simplex algorithm, Press et al. 1986):

$L_{2}=L_{1}+\left(L_{\infty}-L_{1}\right)\left(1-e^{-K\left(t_{2}-t_{1}\right)}\right)$

where $L_{1}$ is the length at marking time $\left(t_{1}\right)$ and $L_{2}$ the length at recapture time $\left(t_{2}\right)$. As our data lack size-increment measurements referring to larger individuals $L_{\infty}$ was not determined iteratively, but set to the maximum length observed.

To compare the VBGF obtained for each period (LN and post-LN) an analysis of the residual sum of squares (RSS) was performed (Chen et al. 1992). The index of growth performance phi prime $\left(\Phi^{\prime}\right.$; for a review see Brey 2001) was used as a measure of growth performance:

$\Phi^{\prime}=\log K+2 \times \log L_{\infty}$

\section{Mortality and longevity}

Total mortality $Z$ (year ${ }^{-1}$ ) was calculated independently for the two periods ( $\mathrm{LN}$ and post-LN) with the single negative exponential model on pooled length-frequency data: 
$N_{t}=N_{0} e^{-Z t}$

(where $t$ is the time and $N_{0}$ is the number of individuals at $t=0)$ and the length converted catch curve on the pooled length-frequency data (Pauly 1983). Thereby, using the parameters of the VBGF, length of pooled lengthfrequency samples was converted into age as:

$N_{i} / \Delta t_{i}=N_{0}^{\prime} e^{-Z t_{i}}$

where $N_{i}$ is the number of individuals in length class $i, \Delta t_{i}$ is the time required to grow through this size class, and $t_{i}$ is the age of the middle size class $i$. Mortality $Z$ is calculated by linear regression analysis:

$\operatorname{Ln}\left(N_{i} / \Delta t_{i}\right)=a+b t_{i} ; \quad Z=-b$

Longevity $(\mathrm{Tm})$ was calculated as:

$\operatorname{Ln}(Z)=a+b \times \ln (T m)$

where $a=1.23$ and $b=-0.832$ are constants, estimated from different mollusc stocks (see Hoenig 1983).

\section{Production}

Total annual somatic production $P_{\mathrm{S}}$ (in $\mathrm{g} \mathrm{AFDM} \mathrm{m}{ }^{-2}$ year $^{-1}$ ) was calculated for the intertidal $C$. affinis belt by the mass specific growth rate method (Crisp 1984) from the mean of quantitative samples, pooled length-frequency data, the VBGF parameters and the size-mass relationship (Eq. 1) for each period ( $\mathrm{LN}$ and post-LN):

$P_{\mathrm{s}}=\sum N_{i} M_{i} G_{i}$

where $N_{i}$ is the mean abundance of individuals $\left(\mathrm{N} \mathrm{m}^{-2}\right)$ estimated from quantitative samples, $M_{i}$ the mean body mass (g AFDM) in length class $i$ and $G_{i}$, the mass-specific growth rate $\left(\right.$ year $\left.^{-1}\right)$ :

$G_{i}=b K\left[\left(L_{\infty} / L_{i}\right)-1\right]$

where $b$ is the constant of the allometric Eq. $1, K$ and $L_{\infty}$ are VBGF parameters and $L_{i}$ is the mean length in size class $i$. Individual somatic production $P_{i}$ (in $\mathrm{g}$ AFDM year ${ }^{-1}$ ) was calculated as:

$P_{i}=\sum M_{i} G_{i}$

and mean annual biomass $\bar{B}$ (in g AFDM m ${ }^{-2}$ year $^{-1}$ ) of the population as:

$\bar{B}=\sum N_{i} M_{i}$

The $\mathrm{P}_{\mathrm{s}} / \bar{B}$ ratio (productivity) of the $C$. affinis population was calculated from annual somatic production $P_{\mathrm{s}}$ and annual mean biomass $\bar{B}$.

\section{Results}

Reproduction

Body mass cycle in relation to GSI and the distribution of reproductive stages is shown in Fig. 2. Animals in the spent stage were found throughout the entire study period. However, a main spawning period, indicated by a clear body mass decrease, a declined GSI and increasing microscopic observations of spent stages between January and March 2001 is evident (Fig. 2). Two minor spawning events occurred from April to June 2000 and 2001. An additional spawning event seems to occur between October and November 2000 as indicated by the strong increase of spent stages, and a decrease of ripe animals. However, no reduction of body mass was observed. In general, higher proportions of ripe animals were observed during $\mathrm{LN}$ compared with post-LN period, whereas GSI values were consistently higher during the post-LN period.

The Spearman correlation analysis showed significant correlations between reproductive and environmental variables: a positive correlation exists between the body mass cycle, salinity and SST anomalies of the Niño $1+2$ region; whereas a negative relationship was observed between body mass cycle and monthly mean precipitation (Table 1; Fig. 3). The latter was higher during LN; in fact, during 2000 it reached $13,939 \mathrm{~mm}$ in comparison to an annual historical (1984-2004) average of $11,435 \mathrm{~mm}$ (Corporación Autónoma del Valle del Cauca 2000). The body mass cycle did not show a clear annual pattern.

Growth, mortality and longevity

In total 815 individuals were marked, of which 181 (22.2\%) were recovered. Estimated VBGF parameters $\left(L_{\infty}\right.$ and $K$ ) and the corresponding $\Phi^{\prime}$ index are given in Table 2. RSS analysis showed that growth during LN was significantly higher $\left(F_{3,175}=9.24 ; P<0.05\right)$ than during the post-LN period. The results of the size-converted catch curves (Fig. 4) indicate a higher mortality rate of $C$. affinis during $\mathrm{LN}(Z=0.53)$ compared to the post-LN period $(Z=0.32)$. Longevity was lower during $\mathrm{LN}$ (9.21 year) than during post-LN (17.25 year).

\section{Production}

Individual somatic production during $\mathrm{LN}$ increased to a maximum of $0.031 \mathrm{~g} \mathrm{AFDM} \mathrm{year}{ }^{-1}$ at $26.5 \mathrm{~mm} \mathrm{SL}$ and decreased thereafter, whereas it was lower during the post$\mathrm{LN}$ period reaching $0.028 \mathrm{~g} \mathrm{AFDM} \mathrm{year}^{-1}$ at $28.5 \mathrm{~mm} \mathrm{SL}$ (Fig. 5). 


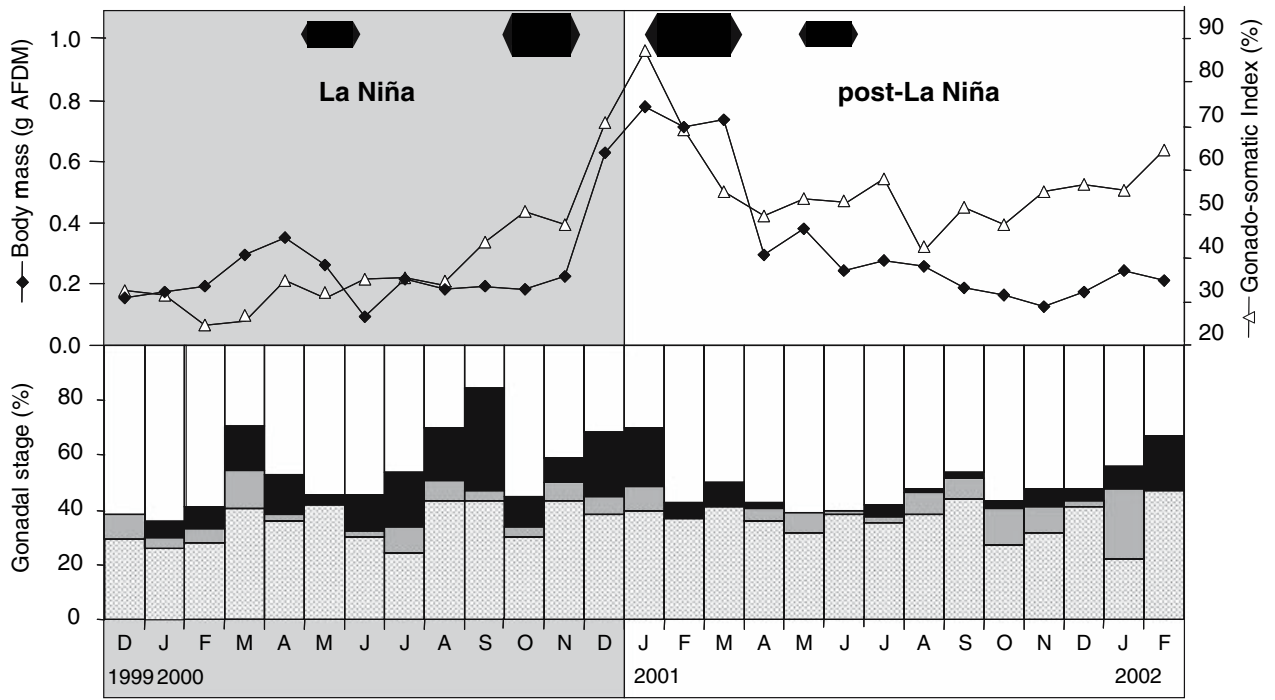

园 Indifferent $\square$ Ripe I $\quad$ Ripe II $\square$ Spent

Fig. 2 Body mass (g ash-free dry mass) cycle for a $30 \mathrm{~mm}$ standard individual (calculated from size-mass relationship, Eq. 1) and reproductive cycle of Cardita affinis based on the gonado-somatic index $(G S I)$ and gonadal stages from microscopic observations of smear samples. Spawning events are indicated by black bars on top:
Bar size corresponds to the extent of the spawning events indicated by body mass decreases; GSI decreases and spent stage increases between successive months. La Niña 1998-2000 chronology based on data from NOAA/National Weather Center-Climate Prediction Center

Table 1 Spearman correlation matrix of reproductive factors and abiotic variables

\begin{tabular}{|c|c|c|c|c|c|c|}
\hline & Body mass & GSI & SST & SAL & MMP & $\mathrm{SST} 1+2 \mathrm{an}$ \\
\hline GSI & 0.3828 & & & & & \\
\hline SST & -0.0141 & -0.1793 & & & & \\
\hline SAL & 0.6132 & 0.0681 & 0.1837 & & & \\
\hline MMP & -0.4957 & -0.3272 & 0.0985 & -0.6436 & & \\
\hline SST1 + 2an & 0.5251 & -0.0110 & 0.0575 & 0.6780 & -0.4729 & \\
\hline$\%$ Spent stage & 0.0393 & 0.0219 & -0.0271 & -0.0770 & -0.1809 & 0.0397 \\
\hline
\end{tabular}

GSI gonado-somatic index, \% spent stage percentage of individuals classified as "spent", SST sea surface temperature of the study area, SST $1+2$ an sea surface temperature anomalies of Niño region $1+2$, MMP: monthly mean precipitation. $P$ values $>0.5$ are printed in bold

Fig. 3 Relationship between body mass cycle of Cardita affinis and environmental variability during the study period. Salinity, sea surface temperature anomalies of Niño region $1+2$ (SST anomalies), monthly mean precipitation in the study area (MMP) from a government agency in Málaga Bay were plotted. La Niña 1998-2000 chronology based on data from NOAA/National Weather Center-Climate Prediction Center

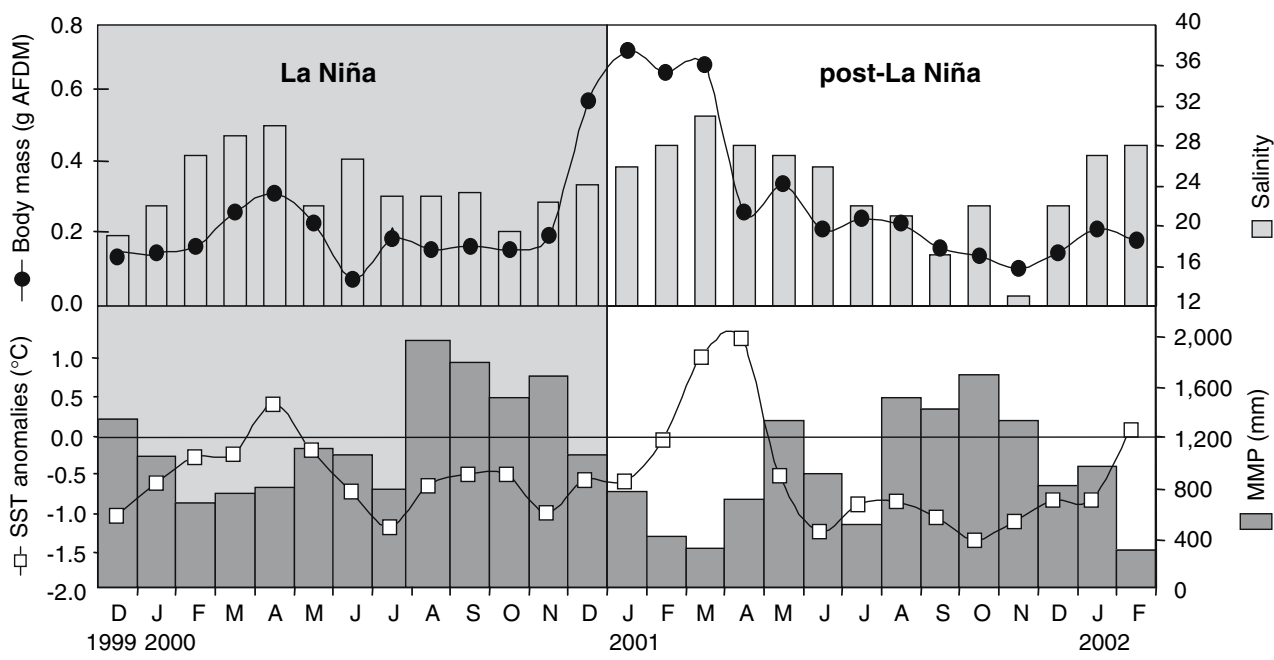


Table 2 Cardita affinis. Von Bertalanffy growth function parameters ( \pm standard error) estimated with Fabens' method (1965) from two marking-recapture experiments (LN and post-LN)

\begin{tabular}{lll}
\hline VBGF parameter & $\begin{array}{l}\text { La Niña } \\
1998-2000\end{array}$ & $\begin{array}{l}\text { Post-La Niña } \\
2001-2002\end{array}$ \\
\hline$L_{\infty}\left(L_{\max }\right)$ & 39.0 & 40.0 \\
$K\left(\right.$ Fabens, $L_{\infty}$ fixed $)$ & $0.233( \pm 0.02)$ & $0.129( \pm 0.01)$ \\
$\% \mathrm{VE}$ & 98.7 & 98.6 \\
$\Phi^{\prime}$ & 2.55 & 2.31 \\
\hline
\end{tabular}

$L_{\infty}$ asymptotic length (mm), $K$ growth constant (year ${ }^{-1}$ ), $L_{\max }$ largest individual of the length-frequency data set, \%VE percentage of variance explained, $\Phi^{\prime}$ index of overall growth performance

The LFD of the $C$. affinis population showed a unimodal size distribution, with medium-sized individuals prevailing. However, during LN larger individuals dominated the population, although the mean abundance was almost the same for the two periods (Fig. 5; Table 3). Taking into account that medium to large sized individuals supported the highest individual somatic production, the shift to smaller individuals during 2001-2002 (post-LN) leads to a reduction of total annual production. The estimates for annual production, annual biomass and $P_{S} / \bar{B}$ ratio are summarised in Table 3.

\section{Discussion}

Cardita affinis showed continuous gametogenic activity (Fig. 2) as it is commonly reported for bivalves from tropical regions, where interannual temperature variability is low (Urban 2001). However, periods of increased activity are still identifiable and often correlated to climatic variation (Urban 2000, 2001; Riascos 2006).

During the study period the reproductive cycle of C. affinis was characterized by: (1) the absence of an evident seasonal spawning pattern (Fig. 2), (2) a lack of correlation between GSI/ body mass versus the percentage of spent animals, and (3) the fact that body mass was the only parameter being significantly correlated with environmental factors (Table 1).

The absence of a seasonal spawning pattern may indicate an abnormal environmental condition the species has to cope with and a low ability to recover the normal rhythm. Some authors described changes in spawning patterns in marine bivalves related to environmental anomalies during ENSO (Birket and Cook 1987; Arntz et al. 1987; Urban and Tarazona 1996). In the study area interannual variability of water discharge and sediment load are associated with ENSO (Restrepo and Kjerfve 2000). During LN Southeast trade winds are well developed and the ITCZ remains north of its typical position (Kjerfve et al. 2001). As a result,

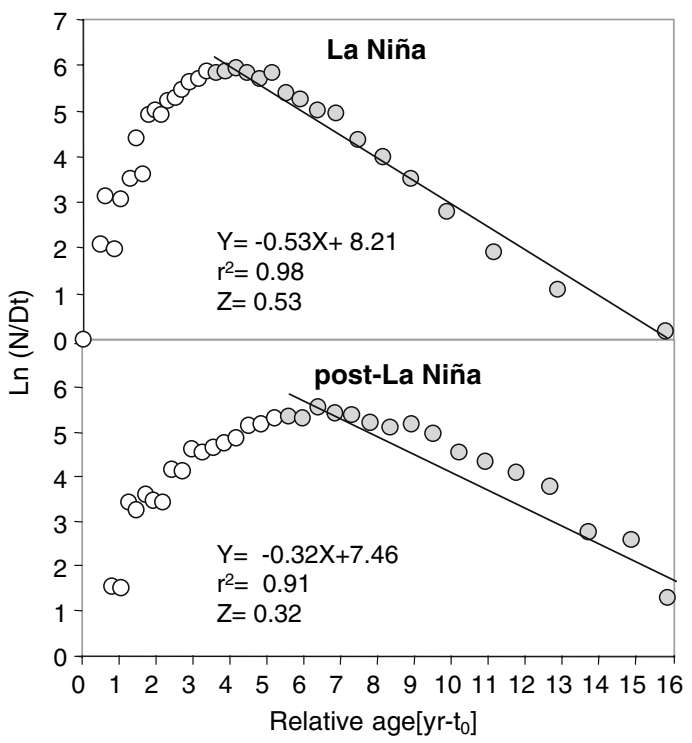

Fig. 4 Length-converted catch curves of Cardita affinis for two periods (LN 1999-2000 and post-LN 2001-2002), based on pooled length-frequency data. Von Bertalanffy growth parameters required for this method are given in Table 2. Filled data points: used for regression; open data points: excluded from regression. Regression equation, $r^{2}$ and $Z$ values are given

rainfall intensifies, thus increasing MMP. This effect is clearly visible in Fig. 3, the MMP showing significant differences $(P<0.05)$ between the $\mathrm{LN}$ and the post-LN period.

The lacking correlation between both GSI/body mass and the percentage of spent animals may be an indication of the species mechanism to face atypical conditions: gamete re-absorption has been observed as a mechanism to reallocate energy to metabolic maintaining under environmental stress (Urban and Tarazona 1996). This mechanism may explain the irregular spawning event observed in September-October 2000, in which the percentage of spent stages increased, but did not correspond with a decrease of GSI and body mass (i.e. gametes were not released). Alternatively, spawning could have taken place, but may have been masked by the increasing trend of body condition and GSI. This explanation is supported by the quick recovery of ripe individuals in December 2000 and January 2001 (Fig. 2). In the last case, we would expect a recruitment event during LN (as recorded during the post LN period) but it did not occur. However, competent larvae may have been recruiting elsewhere or may have died under those anomalous environmental conditions.

The high correlation between body mass changes and the environmental parameters (Table 1; Fig. 3) indicates that environmental variability may be related to food availability. Terrestrial runoff, river discharge and resuspension of bottom sediments by tidal currents have been identified as the principal source of nutrients in tropical 
Table 3 Summary of production estimation for Cardita affinis during La Niña and the following post-La Niña period

\begin{tabular}{lll}
\hline Production factor & $\begin{array}{l}\text { La Niña } \\
1999-2000\end{array}$ & $\begin{array}{l}\text { Post-La Niña } \\
2001-2002\end{array}$ \\
\hline $\begin{array}{l}\text { Total annual production } \\
\left(\mathrm{g}_{\text {AFDM m}}\right)^{-2}\end{array}$ & 1.91 & 1.55 \\
$\begin{array}{l}\text { Annual biomass } \\
\left.(\mathrm{g} \mathrm{AFDM} \mathrm{m})^{-2}\right)\end{array}$ & 5.86 & 6.35 \\
$\begin{array}{l}\text { Annual } \mathrm{P}_{\mathrm{s}} / \bar{B} \text { ratio } \\
\begin{array}{l}\text { Mean abundance } \\
\left(\mathrm{N} \mathrm{m}^{-2}\right)\end{array}\end{array}$ & 0.32 & 0.24 \\
\hline
\end{tabular}
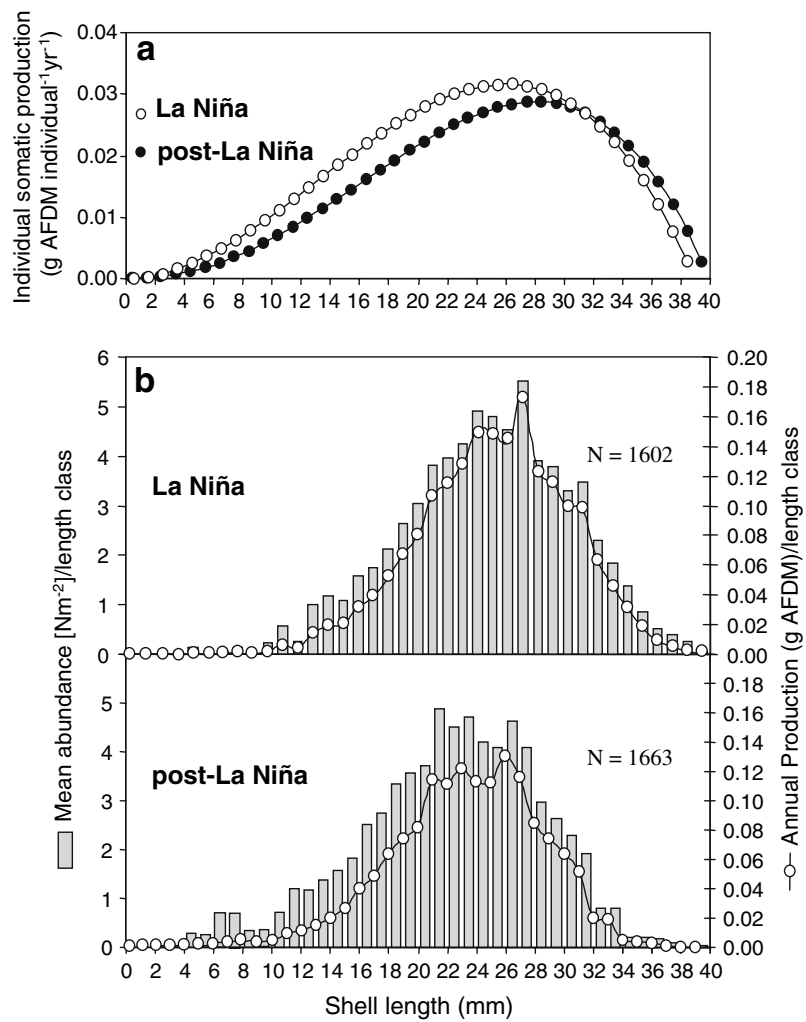

Fig. 5 Individual somatic production and annual population production of Cardita affinis during 1999-2000 (LN) and 2001-2002 (post$\mathrm{LN})$; a individual somatic production for different size classes; b annual population production and mean abundance for different size classes

estuarine ecosystems (von Prahl et al. 1990; Cantera and Blanco 2001; Medeiros et al. 2001), which have a fast turnover rate (Alongi 1994). Thus, it can be proposed that during the rainy season with high river discharge, primary productivity (and thus food availability) raises, as has been observed in tropical estuaries in Costa Rica (Gocke et al. 2001) and coastal lagoons of the Caribbean coast of Colombia (Hernández and Gocke 1990). Therefore, the body mass increase observed during November 2000 and January 2001 and the main spawning event in January/
March 2001 may be related to the abnormally high MMP between August and November 2000 (LN) and the subsequent increase in primary production.

Growth was significantly higher during LN than during the post-LN period, though the asymptotic length was slightly higher during the latter (Table 2). Accordingly, growth performance was higher during LN. Increased growth performances of suspension feeding bivalves could be mainly related to food availability (Peterson 1982; Sastre 1984; Nakaoka 1992; Laudien et al. 2003; Heilmayer et al. 2004). As ENSO-induced increases in freshwater flow seem to boost estuarine phytoplankton biomass and production in tropical estuarine ecosystems (e.g. Abreu et al. 1994; Ciotti et al. 1995), the observed differences in growth performance could be related to increased food availability during LN.

Results on growth and reproduction support the hypothesis of favourable feeding conditions during LN. However, the results on mortality seem to contradict this theory. Mortality was higher during LN, precisely when lowest mortality is expected due to presumably favourable conditions. In a study on the influence of run-off on growth and survival of the Sydney rock oyster, Saccostrea glomerata, Paterson et al. (2003) observed a similar pattern: elevated seston loads associated with low salinities were reflected in an initial increased oyster growth. However, higher mortality rates were reported when runoff was too high. While storms, which temporarily increase turbidity and sedimentation in estuaries, do not necessarily affect bivalves, continued sediment inputs (e.g. river discharge) significantly affect their physiology (Norkko et al. 2006). Anomalous high run-off lasted until the end of 2000, which may initially facilitate growth of C. affinis, but was detrimental when associated stress surpassed the tolerance range of this species, thus leading to both high growth and a higher mortality rate in 2000 . Extended periods of wave and salinity-stress may also promote detrimental effects on sedentary fauna (Ritter et al. 2005; Zardi et al. 2006). Nevertheless, physiological experiments are needed to determine the tolerance to different levels of these stressors and disentangle their relative importance on growth and mortality. Results on mortality are reflected in the observed longevity, which was almost twofold during 2001-2002 in comparison with the LN period. While a life span of 17 years seems too long, it is not unusual for tropical bivalves (see Stern-Pilot and Wolff 2006).

The higher growth rate observed during $\mathrm{LN}(K=0.23)$ compared to the post-LN period $(K=0.13)$ led to a higher individual production, except for the largest individuals (SL $\geq 34 \mathrm{~mm}$ ) (Fig. 5a). The LFD shows that only medium-sized individuals dominated the population and juveniles were scarce (Fig. 5b). This might be the result of 
strong recruitment variability associated to EN 1997-1998 and LN 1999-2000. The strong spawning event observed in January-March 2001 and the return to normal environmental conditions can explain the observed increase of small individuals (7-8 mm) during 2001-2002 (Fig. 5b).

During $\mathrm{LN}$ the $C$. affinis population consisted of slightly larger individuals, even when the mean abundance was almost the same for the two periods (Table 3). Taking into account that medium to large sized individuals supported the highest individual somatic production, the shift to larger individuals during 2001-2002 (post-LN) lead to a reduction of total annual production. Finally, although the annual biomass was lower during $\mathrm{LN}$, the population productivity $\left(P_{s} / \bar{B}\right.$ ratio $)$ was higher, thus giving further support to the assumption of favourable food conditions. The observed differences in productivity of $C$. affinis are consistent with changes in productivity of the surf clam Donax dentifer inhabiting sandy beaches at Málaga Bay (Riascos 2006): productivity during LN 1999-2000 (2.34) was higher by almost a factor of two in relation to that of the post-LN period (1.21). This suggests that $\mathrm{LN}$ brings about strong changes in coastal energy flow.

Population dynamics during ENSO have been mostly studied at higher latitudes, where changes are mainly related to temperature anomalies. Our study shows that in estuarine ecosystems LN modifies freshwater input, which in turn may affect biogeochemistry and primary production in coastal waters (Ciotti et al. 1995), thus promoting changes on growth, mortality, reproduction and somatic production of $C$. affinis. Unfortunately, similar studies on comparable ecosystems and related species are still lacking, thus comparisons are precluded. Owing to this and the fact that interannual variability in population dynamics is expected under normal periods, our study provides a base line for future studies on ENSO-related effects in tropical estuarine ecosystems.

Acknowledgments Special thanks to Angela Perez, Angela Navarrete and Cristina Murillo for their support in field and laboratory work. We are very grateful for the comments of three anonymous referees that improved our manuscript considerably. This study was financed by the Biological Impact Network on ENSO (RIBEN-OEAINCIVA), the EU project CENSOR (Climate Variability and El Niño Southern Oscillation: Implications for Natural Coastal Resources and Management, contract 511071) and the Programa Bicentenario de Ciencia y Tecnología CENSOR-RUE 02 and is CENSOR publication 0112.

\section{References}

Abreu PC, Odebrecht C, Gonzalez A (1994) Particulate and dissolved phytoplankton production of the Patos Lagoon estuary, southern Brazil: comparison of methods and influencing factors. J Plank Res 16:737-753
Alongi DM (1994) The role of bacteria in nutrient recycling in tropical mangrove and other coastal benthic ecosystems. Hydrobiologia $285: 1-3$

Arntz WE (1986) The two faces of El Niño 1982-1983. Arch Fish Mar Res/Arch Fisch (Meeresforsch) 31:1-46

Arntz WE, Fahrbach E (1996) El Niño: Experimento climático de la naturaleza. Fondo de Cultura Económica, México DF

Arntz WE, Brey T, Tarazona J, Robles A (1987) Changes in the structure of a shallow sandy-beach community in Peru during an El Niño event. S Afr J Mar Sci 5:645-658

Arntz WE, Gallardo VW, Gutiérrez D, Isla E, Levin LA, Mendo J, Neira C, Rowe GT, Tarazona J, Wolff M (2006) El Niño and similar perturbation effects on the benthos of the Humboldt, California, and Benguela Current upwelling ecosystems. Adv Geosci 6: 243-265

Birkett D, Cook P (1987) Effect of the Benguela temperature anomaly, 1982-1983, on the breeding cycle of Donax serra Röding. In: Payne AIJ, Gulland JA, Brink KH (eds) The Benguela and comparable ecosystems. S Afr J Mar Sci 5:191-196

Brey T (2001) Population dynamics in benthic invertebrates. A virtual handbook.

http://www.awi-bremerhaven.de/Benthic/Ecosystem/FoodWeb/ Handbook/ Alfred Wegener Institute for Polar and Marine Research, Germany

Cantera JR, Blanco JF (2001) The estuary ecosystem of Buenaventura Bay, Colombia. In: Seeliger U, Kjerfve B (eds) Coastal marine ecosystems of Latin America. Ecological studies. Springer, Heidelberg, pp 264-280

Chen Y, Jackson DA, Harvey HH (1992) A comparison of von Bertalanffy and polynomial functions in modelling fish growth data. Can J Fish Aquat Sci 49:1228-1235

Ciotti AM, Odebrecht C, Fillmann G, Möller OO (1995) Freshwater outflow and subtropical convergence influence on phytoplankton biomass on the southern Brazilian continental shelf. Cont Shelf Res 15:1737-1756

Corporación Autónoma del Valle del Cauca (2000) Base de datos de la Unidad de Monitoreo Ambiental, Cuenca Patia/San Juan. http://www.cvc.gov.co

Crisp DJ (1984) Energy flow measurements. In: Holme NA, McIntyre AD (eds) Methods for the study of marine benthos. Blackwell, London, pp 284-372

Enquist BJ, Jordan MA, Brown JH (1995) Connections between ecology, biogeography, and baleobiology relationship between local abundance and geographic distribution in fossil and recent mollusks. Evolut Ecol 9:586-604

Fabens AJ (1965) Properties and fitting of the von Bertalanffy growth curve. Growth 29:265-285

Garcia FA (2002) Estrategias reproductivas de bivalvos marinos en el noroeste Mexicano. Ph D Thesis Universidad de Colima, Mexico

Gocke K, Cortéz J, Murillo M (2001) The annual cycle of primary production in a tropical estuary: the inner regions of the Golfo de Nicoya, Costa Rica. Rev Biol Trop 49:289-306

Guillou J, Bachelet G, Desprez M, Ducrotoy JM, Madani I, Rybarczyk H, Sauriau PG, Sylvand B, Elkaim B, Glemarec M (1990) Les modalités de la reproduction de la coque (Cerastoderma edule) sur le littoral Francais de la Manche et de l'Atlantique. Aquat Living Resour 3:29-41

Heilmayer O, Brey T, Storch D, Mackensen A, Arntz WE (2004) Population dynamics and metabolism of Aequipecten opercularis (L.) from the western English Channel (Roscoff, France). J Sea Res 52:33-44

Hoenig JM (1983) Empirical use of longevity data to estimate mortality rates. Fish Bull 81:898-903

Hernández CA, Gocke K (1990) Productividad primaria en la Ciénaga Grande de Santa Marta, Colombia. An Inst Invest Mar Punta Betín 19-20:101-119 
Kjerfve B, Seelinger U, Drude De Lacerda L (2001) A summary of natural and human-induced variables in coastal marine ecosystems of Latin America. In: Seeliger U, Kjerfve B (eds) Coastal marine ecosystems of Latin America. Ecological studies. Springer, Heidelberg, pp 341-352

Laudien J, Brey T, Arntz WE (2003) Population structure, growth and production of the surf clam Donax serra (Bivalvia, Donacidae) on two Namibian sandy beaches. Estuar Coas Shelf Sci 58S: $105-115$

Libbey LK, Johnson ME (1997) Upper Pleistocene rocky shores and intertidal biotas at playa La Palmita (Baja California). J Coast Res 13:216-225

Medeiros C, Kjerfve B, Araujo M, Newmann-Leitao S (2001) The Itamaracá estuarine ecosystem, Brazil In: Seeliger U, Kjerfve B (eds) Coastal marine ecosystems of Latin America. Ecological studies. Springer, Heidelberg, pp 71-81

Nakaoka M (1992) Spatial and seasonal variation in growth rate and secondary production of Yolida notabilis in Otsuchi Bay, Japan, with reference to the influence of food supply from the water column. Mar Ecol Prog Ser 88:215-223

Norkko J, Hewitt JE, Thrush SF (2006) Effects of increased sedimentation on the physiology of two estuarine soft-sediment bivalves, Austrovenus stutchburyi and Paphies australis. J Exp Mar Biol Ecol 33:12-26

Paterson KJ, Screider MJ, Zimmerman KD (2003) Antropogenic effects on seston quality and quantity and the growth and survival of Sydney rock oyster (Saccostrea glomerata) in two estuaries in NSW, Australia. Aquaculture 221:407-426

Pauly D (1983) Lengt-Converted Catch Curves. A powerful tool for fisheries research in the tropics. Part I. Fishbyte 1:9-13

Peterson CH (1982) The importance of predation and intra- and interespecific competition in the population biology of two infaunal suspension-feeding bivalves, Protothaca staminea and Chione undatella. Ecol Monogr 52:437-475

Peterson MS (2003) A conceptual view of environmental-habitatproduction linkages in tidal river estuaries. Rev Fish Sci 11:291313

Press WH, Flannery BP, Teukolsky SA, Vetterling WT (1986) Numerical recipes. The art of scientific computing. Cambridge University Press, Cambridge

Restrepo JD, Kjerfve B (2000) Water and sediment discharges from the western slopes of the Colombian Andes with focus on Rio San Juan. J Geol 108:17-133

Restrepo JD, Kjerfve B, Correa ID, Gonzalez J (2002) Morphodynamics of a high discharge tropical delta, San Juan River, Pacific coast of Colombia. Mar Geol 192:355-381

Riascos JM (2006) Effects of El Niño-Southern Oscillation on the population dynamics of the tropical bivalve Donax dentifer from Málaga Bay, Colombian Pacific. Mar Biol 148:1283-1293
Ritter C, Montagna PA, Applebaum S (2005) Short-term succession dynamics of macrobenthos in a salinity-stressed estuary. J Exp Mar Biol Ecol 323:57-69

Ropelewski C, Halpert M (1987) Global and regional scale precipitation associated with El Niño/Southern Oscillation. Mon Weather Rev 115:1606-1626

Rubio E (1984) Estudio taxonómico preliminar de la Ictiofauna de la bahía de Málaga. An Inst Inv Mar Punta Betín 14:157-173

Sastre MP (1984) Relationship between environmental factors and Donax denticulatus populations in Puerto Rico. Estuar Coast Shelf Sci 19:217-230

Stern-Pilot A, Wolff M (2006) Population dynamics and fisheries potential of Anadara tuberculosa (Bivalvia: Arcidae) along the Pacific coast of Costa Rica. Rev Biol Trop 54:87-99

von Bertalanffy L (1938) A quantitative theory of organic growth (inquiries on growth laws II). Hum Biol 10:181-213

von Prahl H, Cantera JR, Contreras R (1990) Manglares y hombres del Pacífico Colombiano. Conciencias-Fondo FEN, Bogotá Colombia

Urban H-J (2000) Culture potential of the pearl oyster (Pinctadda imbricata) from the Caribbean. I. Gametogenic activity, growth, mortality and production of a natural population. Aquaculture 189:361-373

Urban H-J (2001) Reproductive strategies in tropical bivalves (Pteria colymbus, Pinctada imbricata and Pinna carnea): Temporal coupling of gonad production and spat abundance related to environmental variability. J Shellfish Res 20:1127-1134

Urban H-J, Riascos JM (2002) Estimating gonado-somatic indices in bivalves with fused gonads. J Shellfish Res 21:249-253

Urban H-J, Tarazona J (1996) Effects of El Niño/Southern Oscillation on the populations dynamics of a Gari solida population (Bivalvia: Psammobiidae) from Bahía Independencia, Perú. Mar Biol 125:725-734

Wolff M (1987) Population dynamics of the Peruvian scallop Argopecten purpuratus during El Niño Phenomenon of 1983. Can J Fish Aquat Sci 44:1684-1691

Yamashiro C, Rubio J, Taipe A, Aguilar S (2002) Fluctuaciones de la población de concha de abanico Argopecten purpuratus (Lamarck, 1861) en la Bahía Independencia (Pisco, Perú) durante el período 1984-2000 In: Mendo J, Wolf M (eds) Memorias I Jornada Científica Reserva Nacional de Paracas. Universidad Agraria La Molina, pp 77-87

Zardi G, Nicastro K, McQuaid C, Rius M, Porri F (2006) Hydrodynamic stress and habitat partitioning between indigenous (Perna perna) and invasive (Mytilus galoprovincialis) mussels constraints of an evolutionary strategy. Mar Biol 150:79-88 